\title{
A RELAÇÃO CONTINGENTE ENTRE REPRESENTAÇÃO E LEGITIMIDADE \\ DEMOCRÁTICA SOB A PERSPECTIVA DA SOCIEDADE CIVIL*
}

\section{Débora Rezende de Almeida}

\section{Introdução}

Na última década, o conceito de representação política vem ganhando centralidade na teoria política motivado pelas transformações nas relações entre Estado e sociedade que extrapolam a dimensão eleitoral da política. Essa efervescência recente em torno do conceito contrasta com o seu histórico de marginalidade, restrito a algumas referências

* Este trabalho apresenta alguns resultados de minha tese de doutorado defendida na UFMG. Uma versão preliminar deste artigo foi apresentada no $35^{\circ}$ Encontro Anual da Anpocs, em 2011, no GT Controles democráticos e legitimidade. Agradeço os comentários dos participantes e principalmente dos organizadores do GT, Adrian Gurza Lavalle e Paulo D’Ávila Filho.

Artigo recebido em 30/11/2011

Aprovado em 18/12/2012 bibliográficas, entre as quais é notória a influência do livro de Pitkin, de 1967, The concept of representation, e, após quase três décadas, The principles of representative government, de Bernard Manin. Não obstante as diferenças em relação ao diagnóstico das possibilidades do sistema representativo para as democracias contemporâneas, as duas obras seguem as tendências pluralistas e institucionalistas que reduziram o debate da representação à função das eleiçôes, subtraindo do seu mapa conceitual o problema da soberania e de outras formas de representação (Araujo, 2009; Knights, 2009). Desse modo, o conceito de representação limitou-se ao tema do governo representativo e à lógica da representação do Estado (Lavalle e Araujo, 2008; Vieira e Runciman, 2008).

O debate atual vai na direção oposta ao extrapolar os estudos sobre partidos, parlamentos e eleiçôes e focar em diferentes perspectivas para tratar das transformações da representação tanto do pon- 
to de vista das instituições tradicionais quanto das novas instituições e práticas de representação. Assim, a abertura de canais de participação de atores societários, que se colocam como representantes de determinados segmentos e interesses da população na formulação e supervisão de políticas públicas, impõe à teoria pensar seus critérios de legitimidade.

Análises sistemáticas sobre a pluralização da representação política questionam-se, por exemplo, a respeito do significado do próprio conceito de representação política, das características do representante e do representado, dos critérios de legitimidade da representação política e das condiçōes de maior inclusão democrática da representação (Pollak, 2007; Saward, 2005; Castiglione e Warren, 2006; Young, 2006; Phillips, 1995). Os distintos interesses analíticos convergem para duas questôes centrais quando o objeto de investigação são as formas não eleitorais de representação. Primeiro, há uma preocupação em definir o que é representação política e, em segundo lugar, busca-se separar o conceito de critérios de legitimidade associados à autorização e accountability eleitoral, os quais limitam as experiências consideradas representativas.

Essas duas grandes questôes definem o objetivo geral deste artigo. Em relação à primeira, a definição da representação política, existe uma variedade impressionante de adjetivos os quais contribuem mais para esconder do que esclarecer o conceito (Pollak, 2007). Alguns empregados pela teoria são: virtual (Lavalle; Houtzager; Castello, 2006), substantiva, descritiva e simbólica (Pitkin, 1967), promissória, antecipatória, giroscópica e "surrogate" (Mansbridge, 2003), discursiva (Keck, 2003; Dryzek e Niemeyer, 2008), por afinidade (Avritzer, 2007) e autoautorizada (Urbinati e Warren, 2008). Esses adjetivos são usados para denotar diferentes aspectos e dimensões da representação, o que prova a complexidade e arbitrariedade do conceito. Diante dessas dificuldades, o trabalho retoma a discussão entre representação e soberania popular e também discute os limites da concepção eleitoral e pluralista para lidar com as dualidades Estado/ sociedade e unidade/pluralidade, inerentes ao conceito de representação moderna. Em seguida, com base nas transformações recentes na esfera pública, o artigo propõe repensar o conceito de representa- ção política para além da dicotomia eleitor/eleito e da concepção monista, baseada na legitimidade do Estado e do consentimento e, além disso, mapeia debates importantes que tentam repensar o conceito, tendo como norte a resposta às questōes "quem, o que e como se representa”, a partir da consideração das especificidades das distintas experiências.

Em relação à segunda questão, a legitimidade democrática da representação, o artigo apresenta contribuições de Urbinati (2006) e Rosanvallon (2009) no que tange à multiplicação das temporalidades da política e da pluralização das formas e sujeitos da soberania. Propõe que a representação política é um processo que permite o social se tornar político ou que conecta o mundo do político à política. Nessa perspectiva, a legitimidade democrática não está posta apenas nos procedimentos de seleção do representante, mas precisa ser avaliada no processo e a partir da interação entre as diversas esferas deliberativas e representativas (Parkinson, 2003; Hendriks, 2006).

\section{Representação, soberania e governo representativo}

Duas questôes centrais estão na origem da teoria da representação política moderna: como se constitui um poder político legítimo e quais são os limites ao seu exercício. Essas são perguntas que precisam ser respondidas a partir de um contexto de enfraquecimento paulatino dos antigos fundamentos de legitimidade do poder político, como a origem divina do poder real, e o surgimento da concepção contratualista que coloca, de um lado, o Estado como um artefato, uma criação e, de outro lado, os indivíduos dotados de liberdade e igualdade no estado natural. Assim, o pensamento liberal precisa lidar com o problema de pensar a legitimidade do poder soberano e sua compatibilização com a soberania dos indivíduos. O desafio é escapar tanto do dilema da anarquia (todo poder é artificial e, portanto, ilegítimo) como do despotismo (todo poder é artificial e, portanto, absolutamente legítimo) (Santos, 1981).

A resposta liberal-contratualista à conciliação das duas ordens de soberania divide o universo so- 
cial em duas dimensões, uma pública, administrada pelo poder político, esfera na qual os indivíduos abdicaram plenamente de sua soberania, e outra, privada, governada plena e absolutamente pela soberania individual de cada cidadão. A noção de uma soberania divisível permite que o poder político se exerça de forma plena, ao mesmo tempo que é limitado por outra soberania igualmente plena, aquela inerente aos indivíduos. ${ }^{1}$ A questão seria saber em que áreas se renuncia integralmente à soberania e em que áreas ela se mantém. A definição de uma soberania abstrata e a separação entre instituições representativas e cidadãos influenciam de forma categórica a noção de representação e a interpretação do Estado moderno na teoria política. $\mathrm{O}$ exercício da política afasta-se da concepção grega, em que unidade, regulação e identidade do Estado eram concretas, pois eram construídas e preservadas pela participação cotidiana dos cidadãos na gestão pública, e da visão medieval, marcada pela sobreposição de soberanias, fragmentação do poder e critérios fluidos de legitimidade.

O contrato social estabelecido pelo consentimento dos indivíduos é a maneira pela qual se opera a separação entre Estado e sociedade nos diferentes autores contratualistas. Nesse momento, a questão do tipo de governo não era central, mas sim de como conciliar as ordens das soberanias pública e privada. A análise de um dos fundadores mais influentes do pensamento político moderno, Thomas Hobbes, mostra a complexidade do projeto de representação política, no que se refere aos seus polos mais abrangentes: Estado/sociedade, cidadão/indivíduo, liberdade/igualdade, pluralidade/ unidade. As concepções do autor sobre o estado de natureza e os objetivos da formação do poder político influenciaram a definição de qual é o papel do representante e a capacidade de controle do representado. Instituído por contrato social entre os homens, com o objetivo de assegurar a paz e a defesa do bem comum num estado de natureza violento e de guerra de todos contra todos, o soberano hobbesiano deve ser investido de poder absoluto. Ele seria o portador, ao mesmo tempo, da vontade de todos e da sua própria vontade, fazendo que interesse privado e público se aproximassem. Esse arranjo absolutista é possível no pensamento de Hobbes, pois não são os indivíduos particulares, autores da autorização, que são objeto da representação, mas uma pessoa fictícia - o Estado, a Commonwealth, criados pelo soberano (Runciman, 2009; Skinner, 2005). Desse modo, o autor elimina a tensão entre Estado e sociedade suprimindo o individualismo.

As formulações de Hobbes vão de encontro à teoria da representação política apresentada pelos defensores da causa parlamentar na Inglaterra do século XVII. Conforme descrito por Skinner (2005), a noçãa de representação como delegação e autorização já estava presente nos escritos desses autores. Nesse momento, o parlamento deixa de ser visto como instrumento de autoridade real ou de representação do rei para as pessoas, ou seja, uma representação perante o poder, para buscar sua legitimidade como representante do poder. A tradição de corpos representativos locais e a prática de petições coletivas forneceu aos parlamentares o ambiente de um aparente dever de se referir aos seus constituintes antes de tomar decisões (Knights, 2009; Vieira e Runciman, 2008, p. 16). A principal diferença entre os parlamentaristas e Hobbes está na concepção de quem pode congregar os interesses dos representados e de qual é a relação de representação estabelecida entre as partes. Enquanto para os primeiros era fundamental a cooperação entre o rei e o Parlamento, bem como o senso de obrigação para com os representados, para o segundo, o poder absoluto deveria ser o fundamento da soberania.

Essa breve menção aos embates políticos no nascedouro da representação moderna mostra que o conceito estava atrelado ao problema da soberania do poder político, a qual foi definida como a capacidade de agir com autoridade por meio da autorização. Essa é uma discussão que foi subsumida na teoria da representação, tendo em vista a larga compreensão do Parlamento como locus da soberania do poder político e a ideia de soberania como a base do conceito moderno de Estado nacional. Resolvida essa questão, o centro do pensamento liberal clássico se ocupa de saber que tipo de governo era compatível com a defesa das liberdades e da propriedade e qual melhor responderia à conciliação entre esfera pública e privada. A partir da tensão entre a liberdade individual e a necessidade de controlar o representante, os federalistas defen- 
dem a existência de eleições - que exercidas de forma contínua garantiriam o exercício da soberania individual e da liberdade de opinião - e um complexo sistema de checks and balances, inspirado em Montesquieu, que previniria o abuso de poder e a corrupção dos governantes.

É importante lembrar que essa não era uma defesa do sufragio universal, temido pelas possibilidades de tiranias e ameaça à propriedade. ${ }^{2}$ Todavia, com a emergência de poderosos movimentos político-sociais e as pressóes para a abertura do sistema político, de modo a admitir maior participação e ampliar a base do consentimento e da delegação do representante, o liberalismo é obrigado a recorrer a um discurso universalizante, que possa afirmar o interesse coletivo, ao passo que garanta o direito individual da sociedade civil. $\mathrm{Na}$ sua aproximação mais democrática do século XIX, a autorização envolveria o maior número da população, por meio da extensão paulatina do sufrágio (Mill, 1981; Tocqueville, 2000, 2005). O sufrágio universal permitirá, finalmente, o privado se apropriar do público e se enunciar de forma generalizada. De acordo com Rosanvallon (2009), a eleição é uma necessidade procedimental prática para dar conta da busca pela unanimidade, que está presente no ideal político desde o mundo antigo. A eleição mescla dois princípios: o de justificação (identificação, remete à vontade geral do povo nas urnas e, nesse sentido, mantém na origem do regime democrático o desejo de expressar a unanimidade e a generalidade), e uma técnica de decisão (a regra da maioria, que é uma condição de estabelecimento do regime, em que a maior quantidade vale pela totalidade).

A associação entre representação e democracia, materializada nas teorias sobre o governo representativo, dá lugar ao debate sobre a eleição e a accountability. A combinação entre eleições frequentes e a relação de accountability entre representantes e representados, possível pelas características de controle público intrínsecas ao voto, levaria, por dois motivos, o homem a se sentir representado. Primeiro, as eleiçōes operacionalizam a participação dos cidadãos e a expressão de suas preferências, ao considerar de forma matematicamente igual o voto de cada indivíduo. O princípio igualitário, segundo o qual todos os indivíduos têm o mesmo direito de consentir sobre o poder e, portanto, os representantes têm condiçóes de decidir em seu nome, parte do pressuposto de que o cidadão no momento eleitoral situa as diversas alternativas em relação às suas preferências. Em segundo lugar, a eleição também é o momento de realização da accountability, pois permite o veredito dos cidadãos em relação às posições assumidas ou propostas pelos representantes para a formação da agenda pública. Nesse caso, os indivíduos podem fazer um julgamento prospectivo (o que os eleitos deveriam fazer) e retrospectivo (se eles fizeram o que deveria ser feito). Com o tempo, a noção de accountability se sofisticou, bem como as propostas que visaram ampliar o espaço da política e introduzir o elemento da contestação e da contingência da representação. O pluralismo foi central para essa transformação, postulando que o resultado da política é sempre fluido, provisório e dependente da competição entre grupos que se instaura em cada processo. Mas a concepção instrumental do processo político e da política como agregação das preferências dadas permaneceu como única alternativa à realização da democracia.

A dualidade entre representação e representatividade, constitutiva do conceito de representação política, alimentou na teoria política uma série de debates dicotômicos, entre os quais destacam-se a autonomia do representante versus o mandato dos representados; o majoritarismo versus a proporcionalidade; a representação formal versus o seu componente substantivo e a primazia simbólica e política do todo versus a soberania popular ou primazia das demandas e exigências dos eleitores (Lavalle; Houtzager; Castello, 2006). A dificuldade de conciliar a ideia de representação com a representatividade levou também alguns teóricos a advogar um realismo elitista, transformando a política em espaço de competição entre elites (Schumpeter, 1984). Conforme destaca Miguel (2003, p. 135), o principal rebaixamento que o liberalismo provocou no ideal democrático foi o descarte da autonomia como algo utópico, inalcançável, quando não potencialmente perigoso (já que pode conduzir à "tirania da maioria"). A democracia reduziu-se ao usufruto das liberdades na esfera privada e à circulação das elites na esfera política. 
Pitkin (1967) tem um papel fundamental na defesa de uma teoria da representação que recupera a ideia de representatividade e a necessidade de atenção aos interesses dos representados. Para a autora, a representação é uma atividade substantiva, que precisa ser avaliada a partir da capacidade dos representantes agirem de uma forma que promova os interesses dos representados e desses terem os meios para garantir que seus representantes prestem contas de suas ações (Urbinati e Warren, 2008, p. 393). Desse modo, a autonomia política do representante deve ser perseguida, sem que se perca de vista a relação com o eleitorado. Todavia, uma das ambiguidades do seu pensamento é a dificuldade de conciliar a ideia de controle e responsividade aos interesses do representado com a independência do representante. Ao se fixar no paradoxo - representar é tornar presente algo que está literalmente ausente -, Pitkin parece apontar para a necessidade de uma existência prévia ou realidade que precisa ser reapresentada, ao mesmo tempo em que reconhece $\mathrm{o}$ aspecto transformador da representação e o papel ativo do representante. Não fica claro como esse papel criador se concilia com a noção de responsividade - a qual pressupõe atenção às preferências dos representados (Loureiro, 2009, p. 71). O modelo dominante que organiza as democracias contemporâneas, o qual coloca como locus privilegiado da representação o Legislativo e os partidos de massa, acaba sendo a opção da autora para democratização da representação. A representatividade se realiza institucionalmente por meio dos mecanismos do governo representativo.

Análises contemporâneas vêm mostrando a fraqueza desses pressupostos e a necessidade de aperfeiçoamento dos mecanismos institucionais que conectam Estado e sociedade, a partir de dois limites principais do governo representativo. Primeiro, são apresentados os problemas das instituiçōes representativas, partidos políticos, poder administrativo, organizaçóes de interesse, corporaçōes etc., em exercer o papel mediador entre representantes e representados (Rosanvallon, 2009; Schmitter, 1992). Segundo, existem limites estruturais da "democracia eleitoral" para promover o núcleo normativo mínimo da representação política, agir no interesse do representado, bem como tensôes inerentes ao conjunto de dualidades envolvidas na arte de representar. As principais delas referem-se à impossibilidade do princípio da maioria de produzir diagnósticos ou maximizações do que deve ser representado - "interesse geral" ou "vontade da maioria" - e ao controle muito restrito do voto em relação às decisōes tomadas pelos políticos e pela burocracia encarregada de implementá-las (Lavalle; Houtzager; Castello, 2006, p. 59). Visando superar a concepção monista de legitimidade, baseada no consentimento, os estudos apontam para a pluralidade das formas de representar e ser representado.

\section{A pluralidade da representaçáo}

A ampliação do conceito de representação incide diretamente na sua dualidade constitutiva e nas visōes institucionalistas, que apostam no mecanismo eleitoral para operar a ponte entre preferências individuais e decisões políticas. Diante da pluralidade das visões de mundo e das demandas sociais, a transferência formal de poder decisório e a liberdade de expressão na formação da agenda e na organização de grupos são dimensões importantes, mas não suficientes para a democratização do poder político. Essa interpretação desloca a representação para o campo da sociedade civil, reconhecendo uma ampla gama de esferas públicas possíveis em que a cidadania pode ser exercida e os interesses da sociedade não só representados, mas também fundamentalmente (re)modelados (Alvarez; Dagnino; Escobar, 2000, p. 16). A sociedade civil nesse novo contexto luta para redefinir o próprio sentido de representação política e de democracia, colocando em disputa as fronteiras do que deve ser definido como arena política: seus participantes, instituições, processos, agendas e campos de açōes.

Ênfases, focos e análises distintas podem ser encontradas na literatura sobre o papel da participação da sociedade civil na remodelação das instituiçôes representativas e na recuperação de uma noção de democracia como um fim em si mesma, e não como processo meramente instrumental. Participacionistas e deliberacionistas, por exemplo, (re) significam o ideal de racionalidade; a atividade de 
representação política; a maneira de lidar com a intensidade das preferências e da representação encarnar a defesa da universalidade (Pateman, 1992; Habermas, 2003). Todavia, as agendas de pesquisa se encontram fortemente atreladas à ideia de participação, ora como presença direta das pessoas eventualmente afetadas ou beneficiadas por decisões públicas, ora como deliberação face a face. Embora a teoria deliberativa tenha apostado na qualidade discursiva e na formação autônoma das preferências, ela não explica por que aqueles que não participam do processo deliberativo deveriam considerá-lo legítimo (Parkinson, 2003).

A impossibilidade prática de um processo que conte com a expressão de todos os possíveis atingidos tem dado lugar a formas variadas de representação, que não são legitimadas pela autorização de todos, tampouco por sua participação e deliberação. Esses atores, que reivindicam falar em nome de pessoas e/ou grupos "desorganizados", diferenciam-se dos tradicionais grupos de pressão em defesa de seus interesses e, em alguns momentos, localizam-se fora da elite política e econômica. Vários esforços têm sido feitos a fim de analisar em que medida esses atores e espaços estão exercendo representação política, haja vista seu distanciamento dos critérios definidores do conceito, estabelecidos desde a formação do Estado moderno. Por um lado, a riqueza dessas propostas está na variedade de argumentos disponíveis para compreensão da representação. Por outro lado, a maioria dos estudos cobre uma ampla gama de atividades, desde as informais até as mais formais, sem uma preocupação de explicitar estas diferenças, algumas vezes propondo uma interpretação generalizada do fenômeno. Tendo em vista esse problema, o artigo propóe repensar o conceito a partir da redefinição das questôes "quem, o que e como se representa", pois considera que as diferentes respostas a essas perguntas implicam em estratégias metodológicas distintas para se avaliar a prática representativa e sua legitimidade. Sendo assim, é possível pensar na preservação de alguns critérios de legitimidade e princípios fundadores da representação contidos nessas perguntas, como igualdade, inclusão da diversidade, responsividade e prestação de contas, mas a partir de uma revisão da forma de se alcançar tais pressupostos, de modo a incorporar uma compreensão mais plural da representação política.

\section{Quem representa}

A reformulação da representação reflete a pluralidade no exercício da soberania no mundo contemporâneo que precisa lidar com o desafio da ausência de um processo autorizativo de todos os cidadãos. Desse modo, a resposta à questão "quem representa" afasta-se dos critérios de legitimidade pensados na democracia eleitoral - o representante é aquele que fala com autoridade, devido ao consentimento recebido - sem contudo perder o foco na representatividade e na sua capacidade de falar "pelos outros".

A literatura vem mapeando diferentes critérios de legitimidade que estão em ascensão atualmente. Em primeiro lugar, recupera-se a dimensão descritiva da representação. Correntes multiculturalistas e/ou da política da diferença expressam os desafios contemporâneos aos paradigmas democráticos clássicos e à sua capacidade de absorver a diversidade de conflitos existentes (Phillips, 1995; Young, 2000). Diante dos limites da igualdade matemática do voto, ou da igualdade de direitos de cidadania liberais, a teoria democrática vem apontando para a importância de incluir grupos sistematicamente ausentes das esferas políticas e representativas, a partir da diversidade dos grupos sociais, por exemplo, mulheres e minorias raciais e étnicas. Para Phillips (1995, p. 167), a política da presença visa permitir que excluídos lidem mais diretamente com o debate e as decisões políticas. Além da equalização do acesso às elites políticas, Young (2000) defende que a atenção a quem representa tem o objetivo de transformar o próprio modo de fazer política. A política de grupos pode obrigar indivíduos a transformar preferências em reivindicações por justiça e maximizar o conhecimento social de maneira que cidadãos se tornem mais inclinados a tomar decisões justas e sábias.

Algumas propostas para operacionalizar a representação de grupos marginalizados são a adoção de cotas em listas partidárias, representação proporcional, cotas para cadeiras parlamentares e delimitação de distritos especiais. A dimensão des- 
critiva também é uma característica dos espaços de expressão da sociedade civil, como fóruns e "pesquisas” deliberativas e júri de cidadãos. A igualdade de grupos é buscada pela adoção de uma seleção randômica, de modo que os representantes possam espelhar as características da população (Fishkin, 2009; Brown, 2006), ${ }^{3}$ e de uma "representação apropriada”, propondo que os representantes sejam selecionados de forma proporcional ao tamanho do grupo e à intensidade desses interesses no resultado da política (Samuelson et al., 2005). Em relação às propostas que apostam na proporcionalidade, Parkinson (2003, p. 189) ressalta que é preciso observar quais são os objetivos desses fóruns deliberativos, uma vez que a proporcionalidade pode entrar em conflito com o princípio da igualdade. Em alguns momentos é preciso valorizar a participação igualitária de diferenças relevantes na sociedade, e não o princípio estatístico, oferecendo, por exemplo, o mesmo número de mulheres e homens ou o mesmo peso para diferentes grupos étnicos. Esses mecanismos surgem como iniciativa da sociedade ou em parceria com atores governamentais.

Em segundo lugar, está em ascensão a noção de representação como advocacy ou defesa. Urbinati (2006) destaca o papel da sociedade civil na defesa de ideias e temas, de maneira que possam ser incorporados pelo governo representativo. Dryzek e Niemeyer (2008) também alertam para o papel da sociedade na emergência de uma pluralidade de discursos não expressos pela via eleitoral. Essa defesa de causas públicas e coletivas prescinde de qualquer tipo de seleção ou autorização prévia e configura o que Urbinati e Warren (2008) denominam representação autoautorizada (self-authorized representatives). A legitimidade dos grupos de advocacy está posta na afinidade ou identificação de um conjunto de indivíduos com a situação vivida por outros indivíduos (Avritzer, 2007) ou na capacidade de expressarem uma constelação de discursos públicos (Dryzek e Niemeyer, 2008). O que as organizações da sociedade civil, movimentos sociais e indivíduos estão representando na esfera pública é um discurso sobre direitos ou temas, e não um conjunto específico de pessoas.

Isto não quer dizer que os representantes informais estão liberados de buscar autorização nos seus representados. Mas requer uma compreensão diferenciada do que significa autorizar, apartada da noção de preferências que são agregadas nas eleições. A autorização pode ser concedida pelos membros das organizações, quando elas adotam uma filiação voluntária. Ademais, aqueles que reivindicam falar por indivíduos e grupos buscam autorização no reconhecimento público. O reconhecimento dos atores sociais como porta-vozes de temas e políticas se dá na esfera pública discursiva, a partir da justificação pública deses representantes (Maia, 2012). Nesse sentido, a autorização está intrinsecamente conectada aos mecanismos de prestação de contas. Como mostram Castiglione e Warren (2006), onde faltam as eleiçōes, a accountability pode, talvez, reflexiva e retrospectivamente prover a autorização. Esta pode surgir da habilidade de grupos atraírem membros, petiçôes etc.; da convergência de propósitos entre os grupos e seus constituintes; de experiências ou de visibilidade pública e também das características descritivas, tais como gênero e raça.

Em terceiro lugar, existe um tipo de representação da sociedade civil que se tem tornado forte nas áreas de políticas públicas. Nesses casos, atores sociais com determinada especialização temática ou experiência participativa são chamados a partilhar o poder decisório e/ou a discutir em conjunto com atores estatais o destino de algumas políticas. Tanto o Estado quanto a sociedade reconhecem esses atores como interlocutores válidos. Alguns exemplos destas instituições híbridas são os conselhos de políticas, comitês de bacia hidrográfica e Orçamentos Participativos (OP) no Brasil. A representação dos atores coletivos é legitimada pela autorização, a qual envolve uma seleção semelhante às eleições. Em relação à sociedade, há um grupo no qual está a origem da representação exercida por esses representantes. Esse grupo pode incluir ou não todas as associaçôes ligadas ao tema ou mesmo não estar organizado em associaçôes. Estudos vêm apontando a relevância de se avaliar se existem formas transparentes de escolha dos representantes, de maneira a envolver um conjunto amplo da população e a diversidade de perspectivas e de associaçôes diretamente relacionadas com o tema ou a política pública (Almeida, 2010; Lüch- 
mann, 2008). Já os atores estatais geralmente são indicados pelo Poder Executivo.

Nesses mecanismos, a autorização é menos fluida e indeterminada. Além disso, existe uma interdependência entre as questôes, quem e $o$ que se representa, na medida em que a definição de qual é o público que será alvo das políticas deliberadas nessas instituições, em certa medida, influencia o que será representado - tipo de demandas, afinidades e perspectivas que estarão presentes. Tal definição está baseada nas características das políticas públicas que são objeto de deliberação nessas instituiçōes, o que não significa que ela está ausente de contradição. A transversalidade e a complexidade das políticas públicas podem dificultar a identificação do público afetado. Em pesquisas realizadas em diferentes conselhos de saúde e comitês de bacia no país, foi possível detectar, pelo menos, duas direções que têm impacto nas formas de acesso da sociedade. São estas: a) o processo de "seleção", responsável por permitir a disputa aberta entre distintos interesses, opiniōes e perspectivas e b) as regras de composição, uma vez que muitas vezes limitam o tipo de público ou organização que pode disputar uma vaga (Almeida, 2011).

De maneira resumida, o que a seção mostrou é que existe uma variedade de indivíduos e grupos que estão de fato representando, alguns dos quais não possuem autorização expressa. Exemplo ilustrativo é o caso das organizações não governamentais que se declaram defensoras de uma variedade de causas políticas, como o meio ambiente, a proteção dos animais, a pobreza etc. Mas não se pode esquecer que associações de bairro e redes transnacionais de defesa também podem receber um tipo de autorização dos seus membros. Por outro lado, existem atores da sociedade civil que recebem uma autorização específica, seja por parte do próprio Estado, seja da sociedade, obedecendo a um conjunto de regras de seleção. Estes atores que participam de conselhos, por exemplo, têm sido incorporados como parte legítima do processo de negociação de políticas. É importante não perder de vista essas distinções a fim de analisar a legitimidade desses atores e o seu papel na política representativa, que vai desde a influência informal até o poder de compartilhar decisões.
O que se representa?

Em relação à questão "o que se representa", o foco nas eleições privilegiou os interesses ou preferências das pessoas, expressos de maneira matematicamente igual e agregados no momento eleitoral. Essa é uma igualdade demarcada por determinadas fronteiras, em especial territoriais, que parece não responder de forma satisfatória às múltiplas manifestações da soberania popular e da relação entre Estado e sociedade durante o processo de representação política. Diante dos limites dessa igualdade para expressar a pluralidade de interesses e perspectivas sociais, algumas análises propõem repensar o conteúdo da representação sob duas perspectivas. A primeira está relacionada à igualdade matemática propiciada pelo voto que, como observa Rosanvallon (2009), garante o legítimo status de eleito, mas não a qualidade desse processo de inclusão política. A segunda refere-se à crítica à exclusividade da representação de indivíduos e interesses.

No que tange à igualdade matemática, pensada apenas a partir da igualdade eleitoral, teóricos da representação de grupos destacam sua fragilidade para dar conta da diversidade social e da expressão das diferenças. São crescentes as demandas pelo reconhecimento de outras fronteiras de inclusão política que considerem características tais como sexo, raça e renda, que historicamente vêm servindo para excluir indivíduos da representação política, bem como para legitimar a inclusão diferenciada de outros. De acordo com Fraser (2007), a representação política precisa fazer parte de uma das dimensóes de justiça, ${ }^{4}$ defendendo a presença de um componente não geográfico na representação, muitas vezes ausente da discussão focada na igualdade eleitoral. Nessa corrente é possível encontrar várias vozes que advogam pela legitimidade da representação de grupos na arena política e da representação descritiva (Young, 2006; Phillips, 1995), propondo ir além dos tradicionais grupos de influência e pressão necessários à poliarquia democrática, como grupos de interesse, organizações de lobby e partidos políticos. Importa aqui pensar níveis de representação de grupos excluídos do sistema político, como mulheres e negros, a fim de que suas perspectivas possam ser amplamente incorporadas na agenda política. 
Nas palavras de Anne Phillips (1995), trata-se de mudar uma percepçáo arraigada de que a chave da boa representação política está no programa e nas ideias compartilhadas entre representantes e representadas(os) - sem qualquer referência à identidade das(os) representantes. Contra isso, cada vez mais é afirmada a necessidade de presença física dos grupos excluídos nos locais de decisão.

Ao abrir espaço para o papel das identidades dos representantes, a teoria feminista chama a atenção para outras respostas à questão "o que se representa”. Nessa direção, Young (2000) apresenta, ao lado da representação de interesses, a representação de opiniōes e perspectivas sociais. As perspectivas sociais são definidas como "o ponto de vista que membros de um grupo têm sobre processos sociais por causa de sua posição neles" (Young, 2000, p. 137 , tradução da autora). Essa noção permite a defesa da representação descritiva, tanto no campo eleitoral como da sociedade civil, pois atrela a representatividade à existência de determinadas características e experiências compartilhadas e não à defesa de interesses ou indivíduos específicos. Ao mesmo tempo, a autora tenta responder às críticas liberais direcionadas à representação de grupos que apontam o risco de essencialismo presente nessa proposta. Tanto Phillips como Young defendem que a política da presença não redunda na representação automática de alguns interesses de grupos e, portanto, não tem o papel de fortalecer identidades homogeneizadoras. Para Young (2000), as perspectivas sociais são um modo de olhar o mundo e não determinam o que se vê. Nesse sentido, "representar um interesse ou uma opinião geralmente envolve promover certos desdobramentos específicos no processo de tomada de decisão, ao passo que representar uma perspectiva geralmente significa promover certos pontos de partida para a discussão" (Young, 2006, p. 167). A noção de perspectivas sociais se alia também a uma compreensão da representação como relacionamento diferenciado entre atores políticos engajados num processo estendido no espaço e no tempo. Sendo assim, a representação como relacionamento demanda o reconhecimento de diferentes modos de representação, os quais correspondem a diferentes aspectos da vida.
Além das críticas relativas ao risco de essencialização das diferenças (Phillips, 2009), Miguel (2011) discorda da centralidade das perspectivas sociais na compreensão da representação política. $\mathrm{O}$ autor propóe recolocar a categoria dos interesses no centro do debate, bem como restabelecer o entendimento de que a atividade representativa é uma forma de exercício de poder. Dizendo de outra forma, uma noção útil de perspectivas não passa ao largo da relação entre as perspectivas e os interesses. Perspectivas sociais compartilhadas são a base a partir da qual interesses coletivos podem ser construídos. $\mathrm{O}$ autor alerta para a desigualdade social e para os conflitos de interesses presentes na deliberação, que não se esvaem com a inclusão de perspectivas. Nesse sentido, Miguel aposta que a justificativa para inclusão de grupos na política deve vir não da noção de perspectivas, mas de uma defesa de justiça, em que a presença pode dar acesso ao capital econômico, cultural e político, necessário para o exercício do poder (Miguel, 2011, p. 37).

A centralidade dos interesses e do conflito para a política vêm sendo retomada também por uma geração recente de pluralistas e deve, sim, ser considerada na concepção de representação política. Todavia, a defesa dos interesses, como bem reconhece Miguel (2011), é marcada por ambiguidades e imprecisóes. Interesses pretendem uma explicação onipresente, sem, contudo, conseguir explicar qualquer coisa (Schmitter, 2007). Partindo desse pressuposto da dificuldade de lidar com a categoria de interesses já determinados e conscientemente reconhecidos, deve-se levar em conta também o aspecto construtivo da representação, no que se refere à possibilidade do representante criar ou apresentar o interesse do representado. A fim de capturar a diversidade e a unidade, o Estado precisa também agir no lugar do representado e trazer vida a questôes e políticas não expressas previamente pelos indivíduos. Nesse sentido, representar é uma atividade que está ligada tanto à defesa do interesse, ou preferência já existente, como à criação desse interesse ou realidade. Miguel reconhece também essa dimensão construtiva da representação e aponta de forma correta que essa "criação" do representado, contudo, não pode ser arbitrária no sentido de desrespeitar tendências do tecido social, ou seja, 
a representação não pode prescindir do controle e da possibilidade de construção autônoma das preferências dos indivíduos.

O problema é que essas condições parecem bloquear a possibilidade de que a sociedade civil represente interesses de forma democrática. Conforme argumentarei adiante, o reconhecimento da atividade de "criação" do representado pela sociedade civil não substitui a necessidade de formação autônoma dos interesses pelos indivíduos e de controle dos representantes. É preciso atrelar a noção de controle ao julgamento público e ao ideal de revisibilidade e contingência dos resultados, como propõem deliberacionistas e pluralistas (Gutmann e Thompson, 2000; Mouffe, 2005). O processo de representação continua a ser pensado a partir da incerteza e da contingência dos diversos encontros entre Estado e sociedade. A capacidade de a sociedade operar a conexão entre o parcial e o geral está em constante avaliação.

Nesta mesma linha de argumentação, que busca diferenciar representação de interesses e de pessoas de outras formas de representar, Dryzek propõe olhar para a representação de discursos. $\mathrm{O}$ objetivo é fugir da noção de legitimidade como o ato de "contar cabeças", para conferi-la aos acordos provisórios, os quais são consistentes com a constelação de discursos na esfera pública (Dryzek, 2001, pp. 660-665). Tanto a representação liberal de indivíduos como a representação de grupos não são capazes de representar a pessoa em sua integridade e multiplicidade, em virtude da heterogeneidade das identidades coletivas. Para além da representação de grupos e indivíduos, seria preciso pensar em mecanismos para que os diferentes discursos se façam representados. À medida que a representação caminhasse para tal diversidade, os sujeitos ver-se-iam contemplados, inclusive em seus dilemas e tensões, tirando o peso da legitimidade deliberativa que pressupõe que todos devem estar envolvidos (Mendonça, 2010). Essa abordagem tem a vantagem de focar nos discursos não necessariamente expressos pela via eleitoral, uma vez que a agregação de votos não é capaz de reunir as múltiplas dimensões da política moderna. Todavia, uma das críticas à visão discursiva de Dryzek é que existe uma separação entre representação de discursos e pessoas, ao passo que, na prática, discursos são potencialmente constitutivos de identidades e ferramentas que as pessoas reflexivas utilizam para atingir seus objetivos (Avritzer, 2007; Parkinson, 2003). Mendonça (2010) contrapóe esse argumento mostrando que, ao colocar como unidade básica de análise os discursos, Dryzek não destitui os indivíduos de agência. O sujeito continua fundamental na perspectiva discursiva. "Ele não é, todavia, uma essência autônoma e calculista que age apenas para maximizar seus benefícios. O sujeito é um terminal: ele é atravessado por discursos ao mesmo tempo em que afeta estes" (Mendonça, 2010, p. 9-10). Dryzek chega a propor a criação de uma Câmara Discursiva, a qual deveria expressar os diferentes discursos presentes na esfera pública. Embora não tenha sido operacionalizada, é possível perceber que a ideia de discursos é afim com a atuação das sociedade civil nas redes de defesa.

Ao lado dessa discussão ampla sobre o que deve ser represendo, Parkinson (2003, p. 187) prefere defender que em última instância a resposta é "as pessoas afetadas". O autor reconhece, no entanto, que não é possível determinar com grande certeza quem são "as pessoas afetadas", apenas defender que não são os indivíduos unificados da teoria liberal clássica, mas são indivíduos multifacetados, com papéis múltiplos e fluidos, socialmente construídos e com identidades contextualizadas. Apesar de o pertencimento a alguns grupos ser altamente importante, caberá aos indivíduos decidirem a que associaçôes pertencem em cada contexto e, assim, determinar por si próprios quem constitui a comunidade dos afetados a cada momento deliberativo. Nesse sentido, a autonomia do representado está colocada na necessidade de posicionamento político a respeito das demandas e questôes que estão sendo apresentadas pelos representantes informais. Tendo em vista essa concepção multifacetada do indivíduo e a convicção de que sua soberania não se transfere no momento eleitoral, a pluralização de representantes pode contribuir para a qualidade do processo decisório e discursivo. As condições seriam a autonomia do representado e a manutenção do relacionamento com o representante, mesmo que esse relacionamento seja informal, como se verá a seguir. 
Por fim, é possível citar a proposta de Saward (2006) e sua definição de representative claims. O autor argumenta que é necessário focar mais na dinâmica do que nas formas de representação, destacando a contingência e contestabilidade de todas as suas formas. A representação pode ser conceituada em termos de reivindicações/demandas representativas por uma variedade de atores políticos, em vez de vê-la como o resultado alcançado, ou potencialmente alcançável, a partir das eleições. A audiência é livre para interpretar tais demandas e retorná-la ao seu criador. Em princípio, nenhuma reivindicação é boa ou má ou está restrita a interesses, necessidades, desejos, preferências ou perspectivas. A representação política é um processo criativo, no qual o constituinte nunca está dado, como pressupóe o momento eleitoral, mas é construído politicamente.

As disputas em torno da questão "o que deve ser representado" podem tomar forma de uma oposição estéril se levadas ao extremo. Este trabalho propõe olhar para as situações distintas de representação, conforme apresentado na seção anterior. Desse modo, a ênfase na noção de perspectivas como essencial para a construção de interesses, destacada de forma mais tímida em Young (2000) e ressaltada por Miguel (2011), constitui um importante elemento das propostas de representação descritiva, seja a eleitoral, seja a adotada em espaços deliberativos. $\mathrm{O}$ que não significa que está ausente de outras formas de expressão de reivindicações, como aquelas assumidas por grupos de advocacy ou em mecanismos de formulação de políticas públicas. Nos conselhos de saúde do Brasil, por exemplo, a representação de grupos ligados diretamente a certas patologias ou perspectivas de mulheres, indígenas e negros ${ }^{5}$ é tanto adotada como recomendada pelas instruçóes normativas federais. Uma das diferenças em relação a esses espaços no que diz respeito ao que é representado é a autoridade - grau de poder decisório - e a posição que ocupam no espaço institucionalizado do poder político. Enquanto nas redes de advocacy e nos espaços informais de deliberação o que se representa são discursos e ideias sobre direitos ou temas perante o poder político, responsável e autorizado a tomar as decisões, nos espaços híbridos de formulação de políticas há uma representação de temas, discursos e políticas diretamente pelos atores da socie- dade civil. Esses atores atuam na esfera pública, mas também estão inseridos de modo direto no espaço político formal. Mais do que apresentar demandas representativas, como coloca Saward (2006), há uma representação do poder, pois os atores coletivos recebem autorização para tomar decisões em nome das pessoas que serão afetadas pela política. Essas diferenças mostram que é preciso introduzir uma quarta questão à compreensão da representação, a saber, onde se representa. Entender as particularidades dos diferentes modos de representação é essencial para a análise de sua legitimidade.

Em todas essas modalidades, no limite, como bem colocou Parkinson, serão representadas as pessoas afetadas, uma vez que discursos e vozes em defesa do meio ambiente, dos direitos reprodutivos das mulheres, da liberdade de expressão e por aí em diante afetam as pessoas e a forma como vivem e se relacionam. Mas existe uma diferença na sua atuação que mantém a distinção clássica da representação que se exerce perante o poder, como era o caso dos corpos intermediários e do Parlamento, na pré-modernidade, e a representação do poder (Vieira e Runciman, 2008). É importante lembrar ainda que essa é uma construção que se dá em concomitância com outros representantes eleitos e informais e que não exclui a possibilidade de que processos de formação autônoma das preferências dos indivíduos sejam defendidos e buscados.

\section{Como se representa?}

Para Miguel (2011), o fato de atores da sociedade civil desempenharem papéis que contribuem para o bom funcionamento da democracia, incluindo temas e promovendo a defesa de interesses que, de outra maneira, estariam ausentes, não significa que essa forma de representação seja democrática. Análises como a de Avritzer (2007) e Lavalle, Houtzager e Castello (2006) falham ao apontar essas experiências como democráticas, na medida em que faltam a elas tanto legitimidade - dispositivos institucionais de autorização e prestação de contas como uma preocupação com a autonomia dos representados e a formação das preferências políticas. A crítica, embora tenha seus méritos de introduzir a importância dos mecanismos de controle, não 
resolve a questão, pois não percebe outras possibilidades de se prestar contas e exercer responsividade. Além disso, a representação da sociedade civil não se pretende monopolista, na medida em que o campo de reivindicações e formação de preferências está aberto à competição de diferentes vozes, permitindo que preferências formadas autonomamente pelo processo de participação política continuem a se manifestar e a (re)modelar a representação política. É possível estabelecer um diálogo com as pessoas ou grupos "afetados" pela representação, sem que para isso ocorra um consentimento explícito.

O fato de a sociedade não arbitrar sobre a seleção do representante não significa que ela não possa julgar as atividades realizadas pela sociedade civil, tanto em relação à representação de seus interesses, valores e perspectivas quanto em relação à sua interpretação e percepção das demandas e necessidades do representado. Contudo, uma questão central que se coloca é como seria possível manter a habilidade de julgamento, se faltam a essas experiências as eleiçôes. De acordo com Vieira e Runciman (2008, p. 152), mesmo na ausência de sanção legal ou julgamento eleitoral, representantes da sociedade civil podem ser accountables, no sentido de oferecer ao público razões que justifiquem suas escolhas e atividades. A representação política democrática repousa sobre a possibilidade de um relacionamento dialógico que disponibilize possibilidades de objeção por parte do representado, interação constante e abertura à revisão dos resultados (Urbinati, 2006; Mansbridge, 2003).

Outro ponto importante, que está relacionado com a discussão anterior sobre o que se representa, é que a representação democrática não pressupõe apenas congruência e resposta aos anseios dos representados, mas também a construção de espaços e a sustentação de oportunidades para a troca de valores, pontos de vista e interesses (Saward, 2006; Abers e Keck, 2008; Mendonça, 2008). O estabelecimento de demandas legítimas de representação depende do julgamento. Essa é uma perspectiva relacional que implica tratar ambos os lados da relação representativa como relavantes (Plotke, 1997). Traduzindo de forma mais simples, considerando as questôes que orientam este trabalho, quem representa não deve ser julgado separadamente de sua atividade de representação em termos do que e como se representa. Essa perspectiva impóe, em certa medida, uma revisão do conceito de representação, tal qual consolidado por Hanna Pitkin. Representar não é uma atividade de tornar presente a ausência, ou agir no interesse do outro, pela delegação recebida. Não existe um papel passivo do representado ou uma ausência a ser preenchida pelo representante. Essa é uma atividade que deve estar aberta à objeção e à interação constante. Nessa direção, o enfoque recente da teoria deliberativa pode ajudar a restabelecer a conexão entre deliberação e representação, trabalhada de maneira restrita pelos teóricos do governo representativo. A publicidade e a interação deliberativa entre representantes e representados não são atributos do momento fundacional da representação, mas perpassam toda a compreensão $\mathrm{da}$ atividade representativa.

A accountability e a responsividade continuam como critérios básicos de legitimidade democrática, mas sem se limitar à existência de eleições. Ademais, é preciso considerar que fóruns deliberativos selecionados aleatoriamente, por autoindicação, indicados ou eleitos por um grupo específico - produzem decisões e debates de forma diferente da maioria dos indivíduos, em razão do tempo para se informar, debater e mudar preferências. Apesar de não serem accountables a um constituinte específico, os atores sociais precisam prestar contas publicamente de suas açôes, no sentido de apresentar razões pelos direcionamentos que tomam.

No caso dos espaços de deliberação de políticas públicas, o controle pode ser feito de uma maneira um pouco mais direta. Tendo em vista a existência de um mandato, que conecta os atores coletivos a determinadas associações e estabelece o tempo em que são seus representantes, o controle pode dar-se para além da interação informal. Representantes da sociedade civil têm o direito de discutir conjuntamente com os membros da associação os rumos da política pública e estes devem ter espaço para cobrar explicações sobre as decisões tomadas. Além disso, os representantes podem estabelecer uma justificação pública com as pessoas afetadas pelas políticas, uma vez que as características desses espaços os direcionam para um público beneficiário, como no caso dos conselhos de idosos, juventude, criança e adolescente etc. Por fim, tendo em vista o caráter híbri- 


\section{Quadro 1}

\section{A Pluralidade da Representaçáo Política Contemporânea}

\begin{tabular}{|c|c|c|c|c|}
\hline Representação & $\begin{array}{l}\text { Seleção do } \\
\text { representante } \\
\text { Quem? }\end{array}$ & $\begin{array}{l}\text { Sentido da } \\
\text { representação } \\
\text { Oquê? }\end{array}$ & $\begin{array}{l}\text { Relação com o } \\
\text { representado } \\
\text { Como? }\end{array}$ & $\begin{array}{l}\text { Esfera de atuação } \\
\text { Onde? }\end{array}$ \\
\hline Eleitoral & Eleito & $\begin{array}{l}\text { Interesses e } \\
\text { preferências de } \\
\text { indivíduos }\end{array}$ & $\begin{array}{l}\text { Accountability } \\
\text { horizontal e vertical. } \\
\text { Responsivo às } \\
\text { preferências agregadas }\end{array}$ & $\begin{array}{l}\text { Espaço político } \\
\text { eleitoral }\end{array}$ \\
\hline Eleitoral Descritiva & $\begin{array}{l}\text { Eleito com base } \\
\text { na similaridade } \\
\text { de características, } \\
\text { experiências ou } \\
\text { perspectivas sociais }\end{array}$ & Perspectivas sociais & $\begin{array}{l}\text { Accountability } \\
\text { horizontal e vertical. } \\
\text { Responsividade } \\
\text { impulsionada pelo } \\
\text { compartilhamento de } \\
\text { perspectivas }\end{array}$ & $\begin{array}{l}\text { Espaço político } \\
\text { eleitoral }\end{array}$ \\
\hline $\begin{array}{l}\text { Descritiva } \\
\text { (Pesquisas } \\
\text { deliberativos, } \\
\text { júri de cidadãos } \\
\text { e conferências de } \\
\text { consenso) }\end{array}$ & $\begin{array}{l}\text { Indivíduos e grupos } \\
\text { selecionados } \\
\text { aleatoriamente } \\
\text { (sorteio) ou } \\
\text { proporcionalmente }\end{array}$ & $\begin{array}{l}\text { Perspectivas sociais; } \\
\text { discursos e interesses } \\
\text { de indivíduos e } \\
\text { grupos }\end{array}$ & $\begin{array}{l}\text { Justificação pública; } \\
\text { controle pela } \\
\text { mídia; referendos e } \\
\text { plebiscitos }\end{array}$ & Esfera pública \\
\hline Defesa - Advocacy & $\begin{array}{l}\text { Organizações da } \\
\text { sociedade civil, } \\
\text { movimentos } \\
\text { sociais, mídia e } \\
\text { indivíduos que são } \\
\text { auto-autorizados, } \\
\text { eleitos, indicados ou } \\
\text { reconhecidos pelos } \\
\text { membros do grupo }\end{array}$ & $\begin{array}{l}\text { Discursos; interesses } \\
\text { e perspectivas com os } \\
\text { quais se identificam }\end{array}$ & $\begin{array}{l}\text { Justificação pública; } \\
\text { controle pela mídia; } \\
\text { controle mútuo } \\
\text { entre organizações e } \\
\text { redes; mecanismos } \\
\text { democráticos de } \\
\text { associação e interação } \\
\text { entre membros }\end{array}$ & Esfera pública \\
\hline $\begin{array}{l}\text { Atores } \\
\text { Coletivos } \\
\text { (Instituiçóes } \\
\text { híbridas: conselhos } \\
\text { de políticas; } \\
\text { comitês de bacia, } \\
\text { OP) }\end{array}$ & $\begin{array}{l}\text { Conselheiros da } \\
\text { sociedade eleitos ou } \\
\text { indicados (entre um } \\
\text { público restrito) }\end{array}$ & $\begin{array}{l}\text { Discursos; interesses, } \\
\text { perspectivas e } \\
\text { temas que tocam } \\
\text { coletividades e } \\
\text { indivíduos }\end{array}$ & $\begin{array}{l}\text { Justificação pública } \\
\text { diante dos afetados; } \\
\text { interação e controle } \\
\text { entre membros e } \\
\text { controle dos atores } \\
\text { estatais }\end{array}$ & $\begin{array}{l}\text { Esfera pública em } \\
\text { interseção com espaço } \\
\text { político }\end{array}$ \\
\hline
\end{tabular}

Fonte: Elaboração própria, a partir das principais características dos espaços e atores representativos.

do dessas instituições, eles estão sujeitos ao controle direto dos atores estatais, com os quais deliberam.

Em relação aos atores que exercem advocacy, diferentes formas de prestação de contas são destacadas pelos autores. Saward (2005) fala da pos- sibilidade de que hierarquias informais e o relacionamento criado em networks sejam capazes de constranger a comportamentos accountables. Mendonça (2008) destaca o estabelecimento de fluxos internos e externos de comunicação entre represen- 
tantes e representados que permitam o teste permanente da pretensão de representação. Castiglione e Warren (2006) salientam os mecanismos democráticos de associação e interação entre membros de organizaçōes. Por fim, Lavalle, Houtzager e Castello (2006) consideram o papel da mídia para publicização dos atos dos representantes da sociedade civil (Lavalle; Houtzager; Castello, 2006).

No que tange aos espaços de representação descritiva, para além da interação entre representantes informais e representados, viabilizada pela publicidade ou debate informal, existe um controle mais direto já testado empiricamente. Brown (2006) mostra que na experiência de assembleia de cidadãos, promovida em British Columbia para discussão do sistema eleitoral, um referendo foi adotado após o experimento a fim de contrabalançar a opinião que emergiu do processo deliberativo com a recomendação direta da população. Ao submeter aos cidadãos afetados pela política as ideias defendidas por representantes eleitos e por aqueles randomicamente selecionados, o experimento inovou em termos de prestação de contas e responsividade. Apesar dos embates que possam surgir dessas distintas consultas públicas, eles podem ter o potencial de conectar o julgamento de elites políticas, representantes autoautorizados e a população (Urbinati e Warren, 2008, p. 46).

Todas essas alternativas mostram que é possível pensar formas não institucionalizadas de prestação de contas e manutenção do julgamento dos representados, o que não significa que elas necessariamente ocorrerão. John Gaventa (2004), a partir de diferentes estudos que focam na representação de líderes comunitários, revela as dificuldades de manutenção do relacionamento entre representantes, suas entidades e o público em geral, ao passo que se tornam mais ativos e envolvidos em parcerias. Além disso, a seleção desses grupos pode obedecer a uma lógica de cooptação dos representantes eleitos em relação aos representantes da sociedade civil, de maneira a escolher líderes com os quais os primeiros se sintam confortáveis de trabalhar em conjunto. Esses resultados revelam a importância da conexão entre representação e participação, uma vez que a legitimidade democrática continua a depender do julgamento político dos representados.

\section{Representação e soberania e o problema da legitimidade}

Para avançar na compreensão dos atores e espaços plurais da contemporaneidade, um último passo precisa ser dado, a saber, a redefinição da própria representação política e a avaliação de sua legitimidade. Isso implica retomar uma discussão abandonada nos primórdios do conceito, no que diz respeito ao atrelamento de representação e soberania. Para Araujo (2009), Urbinati (2006) foi quem conseguiu fazer essa aproximação de forma mais interessante. Inspirada nas propostas de multiplicação das temporalidades, formas e sujeitos da soberania propostas por Condorcet, Urbinati situa a eleição como uma entre as múltiplas dimensões da representação e da relação entre Estado e sociedade civil. A autora pretende retomar a centralidade da representação para a política democrática, mostrando que essa é mais do que um sistema de divisão de trabalho e uma instituição do Estado, implica um complexo processo político que ativa o "povo soberano" muito além do ato formal de autorização eleitoral (2006, p. 5). Com auxílio também da filosofia kantiana, Urbinati propõe deslocar a importância da vontade na constituição da soberania. Como observa Araujo (2009, p. 56), não se trata de identificar a representação com o soberano, mas sim de pensá-la como um processo de unificação, cujo horizonte é a soberania, não como pessoa concreta, individual ou coletiva, mas como, nos termos anglicistas de Urbinati, um as if kantiano, um ideal regulativo.

A partir da concepção do indivíduo como fonte de julgamentos, ideias e opiniōes, a autora dá vida a uma política representativa que não é passiva, como pretende a teoria da autorização, mas é formada por uma relação ativa entre governantes e governados. Desse modo, quando o indivíduo consente na formação do poder político, ele não está entregando sua vontade ou transferindo sua soberania, mas apenas exercendo um julgamento político. A eleição, desse modo, não é um ato de vontade e transferência da soberania, mas expressa um julgamento político realizado num dado momento. $\mathrm{O}$ dualismo entre Estado e sociedade é superado na medida em que o primeiro precisa ser constantemente recriado e dinamicamente ligado à sociedade a fim de passar leis. 
A representação para Urbinati não estabelece uma distinção fixa entre Estado e sociedade, mas transforma e expande a política posto que permite que o social seja traduzido no político, bem como facilita a formação de grupos políticos e identidades (2006, p. 37).

A teoria de Urbinati é bastante conhecida e analisada. Um dos problemas percebidos por alguns autores é o peso crucial dado aos partidos políticos como mediador da relação Estado e sociedade, advertindo que a realização do potencial existente na representação só se efetiva através da política partidária (Loureiro, 2009, p. 86). O papel dos partidos é o de integração da multidão, unificando ideais e interesses da população e tornando o soberano permanentemente presente como agente de influência e supervisão extraestatais. $\mathrm{O}$ povo soberano retém um poder negativo que lhe permite investigar, julgar, influenciar e censurar seus legisladores. O poder é negativo por duas razões: tem a função de parar, controlar ou mudar um dado curso de ação e pode ser expresso tanto por canais diretos de participação, como referendo e recall, e por meio de participação indireta e informal, tais como fóruns sociais, movimentos, associações civis, mídia e demonstraçōes de rua. Para Avritzer (2007), ao confinar à sociedade o poder negativo, Urbinati não consegue pluralizar as fontes que geram o julgamento político de modo a integrar as novas formas de representação ao conceito que ela propõe. Embora avance no sentido de conceber a participação como constitutiva da representação, a forma do social se tornar político permanece vinculada à lente da participação.

Apesar desses limites, é importante prestar atenção na sua contribuição para a discussão sobre soberania e representação. Conforme argumenta Araujo (2009, p. 55), Urbinati não estabelece uma separação fixa entre dois polos - Estado e sociedade - na qual a representação precisa se encaixar, conforme fórmula tradicional do liberalismo. É a representação que cinde o espaço social, produz e reproduz esta cisão entre Estado e sociedade, redefinindo as fronteiras móveis dessa separação, em sua própria atuação. Esta noção dinâmica da representação como atividade que opera a mediação entre as di- versas parcialidades da vida social e a política é central para a compreensão da representação política como ato de manifestação da soberania. Contudo, ao apontar que a representação opera a cisão entre Estado e sociedade, a autora aposta nas instituiçōes representativas clássicas para fazer essa mediação.

Atualmente existe uma crescente literatura que se devota a tornar a representação democrática algo mais diverso e complexo, conforme discutido até o momento. Rosanvallon se insere nessa perspectiva ao se preocupar com a pluralização das fontes de legitimidade democrática, tendo em vista as dificuldades da política representativa tradicional de expressar a generalidade social. A partir de uma abordagem metodológica e teórica distinta daquela apresentada por Urbinati, ${ }^{6}$ a qual denominou "história conceitual do político", o autor propõe a "compreensão da formação e evolução das racionalidades políticas, ou seja, dos sistemas de representações que comandam a maneira pela qual uma época, um país ou grupos sociais conduzem sua ação e encaram seu futuro" (Rosanvallon, 1995 apud Silva, 2009, p. 7). Nessa linha interpretativa, Rosanvallon (2006) percebe a importância de se avaliar constantemente a institucionalidade da representação política, tendo em vista os limites do momento eleitoral para dar voz a um povo que só existe em sua forma instantânea e evanescente. Para o autor, o povo só pode ser conhecido por uma espécie de representação expandida e refratada. A partir dessa contribuição, é possível repensar a ideia de representação política não como cisão entre Estado e sociedade, mas como atividade que permite ao social se tornar político, ou que conecta o mundo do político à política.

O autor $(2006,2009)$ assume a defesa da pluralização das formas e sujeitos da soberania com o objetivo de superar primeiramente o aspecto ambíguo e paradoxal da representação do Estado. A ambiguidade está posta no fato de que o Estado, pensado para ser a expressão da vontade popular, oferece apenas uma versão distorcida ou parcial dessa. A segunda contribuição refere-se à tentativa de reconciliação do social com o político, que toca diretamente na crítica marxiana do divórcio operado na modernidade entre o homem e o cidadão. A busca pela superação da ambiguidade ou da "di- 
ficuldade de figuração da democracia” se dá por um enfoque plural de encarar a generalidade social, que inclui como fontes de representação política não apenas o Estado, mas um conjunto de instituiçôes e atores, cada qual com suas características e maneiras de corporificar a generalidade social. Baseado na constatação de que as duas formas de expressar a generalidade social, pensadas pela teoria política até o fim do século XX - as eleições e o poder administrativo - entram em crise, principalmente, a partir da década de 1980, o teórico francês sugere repensar a legitimidade democrática da representação. Sua proposta inclui novas figuras de legitimidade ligadas às ideias de imparcialidade, reflexividade e proximidade. Buscando fugir do unânime - a representação como expressão da totalidade social - e do monismo - o interesse social concebido como a propriedade estável de um corpo coletivo ou de uma estrutura - Rosanvallon retoma o ideal de uma soberania complexa e das parcialidades da vida social. A representação é um processo permanente e aberto à revisão.

Para cada tipo de legitimidade - imparcialidade, reflexividade e proximidade - Rosanvallon (2009) elenca um conjunto de instituiçõos que teriam o papel de expressá-las. ${ }^{7}$ Para os fins deste trabalho, importa ressaltar sua visão sobre as figuras de proximidade, diretamente relacionadas com o governo representativo e a atuação da sociedade. As diferentes manifestações e instituições da sociedade civil são percebidas como parte do que designa de "democracia de interação", ou seja: a atuação da sociedade deve ser avaliada não pelo seu estatuto de eleito, mas pela qualidade de interação. $\mathrm{O}$ autor percebe duas funções políticas da democracia de interação. A primeira é a justificação, a qual permite a confrontação de explicações do poder com as intervençōes da sociedade. A segunda é a informativa, na medida em que permite um intercâmbio de informaçôes entre o poder e a sociedade (Rosanvallon, 2009, pp. 300-301). Existem uma série de problemas advindos dessa formulação, impossíveis de serem discutidos neste espaço. Entre eles está a necessidade de pensar as sobreposições e articulações das distintas figuras de legitimidades nas instituiçōes e atores da sociedade. Ademais, pode-se argumentar que as funções desses atores extrapolam o papel de justificação e informação, principalmente nas instituições híbridas brasileiras, como os conselhos de políticas. Nesses espaços há um intercâmbio entre Estado e sociedade e a partilha do processo decisório. Por fim, Silva (2009) destaca os riscos que acompanham a afirmação das legitimidades emergentes, como aqueles relacionados ao populismo que pode estar embutido na radicalização das práticas fundadas na ideia de proximidade.

Para os objetivos conclusivos deste trabalho, importa apenas destacar que a maior contribuição de Rosanvallon para a ampliação do debate sobre representação é a noção de que a legitimidade não é atributo exclusivo do procedimento (status), mas pode ser construída de maneira substantiva, durante o processo de representação (qualidade). A representação da sociedade civil pode, desse modo, contribuir para aproximar estes dois momentos, a legitimação eleitoral e a justificação política, apontando para maior conexão entre a legitimidade construída a partir da ideia de unidade e a dimensão da pluralidade. Esse movimento entre parcialidade e generalidade, centrais para a representação, pode ser facilitado pela abertura das associações para um conjunto diversificado de arenas deliberativas.

Alguns autores da teoria deliberativa, preocupados com a avaliação democrática desses encontros entre Estado e sociedade, propõem que a legitimidade da representação depende em parte de ver esses diferentes espaços e atores como fazendo parte de uma sistema deliberativo mais amplo. Assim, a avaliação da legitimidade pela qualidade, tal qual posta por Rosanvallon, precisa levar em consideração a interação entre as distintas esferas discursivas, micro, macro e mista, ${ }^{8}$ e como a articulação e os possíveis atritos entre elas podem influenciar a atividade representativa e a capacidade dos atores da sociedade civil "falar" em nome de temas, experiências e interesses de outros (Parkinson, 2003; Hendriks, 2006).

Hendriks faz questão de ressaltar que a relação entre as diversas esferas nem sempre é harmônica, mas não consegue indicar formas de promover a articulação entre arenas. Embora se frise que fóruns deliberativos devem ser atravessados pela esfera pública, não há sugestões específicas sobre como desenhar fóruns mais permeáveis e sobre como lidar 
com os possíveis atritos entre esferas (Mendonça, 2010). Esses são problemas que precisam de pesquisa empírica e desenvolvimento mais aprofundado. Importa destacar neste momento que a compreensão da representação, não como uma ação singular de cada indivíduo ou instituição, mas como um sistema complexo e plural - em que emergem várias atividades e esferas de deliberação (Hendriks, 2006; Parkinson, 2003) e as distintas generalidades evocadas pelas mesmas (Rosanvallon, 2009) -, abre caminho para um conceito mais realista da política representativa. Esse, porém, não é o realismo minimalista, oferecido por Schumpeter, que aprisiona a política ao funcionamento das instituiçōes, mas é uma teoria realista-positiva da democracia, como a define Rosanvallon: "realista, porque considera as práticas concretas dos governantes e sua distância dos governados. Mas positiva, porque traça o caminho para uma reapropriação social efetiva do poder" (2009, p. 318, tradução da autora).

A contribuição que Hendriks traz com seu sistema integrado deliberativo está justamente em pensar de maneira dinâmica o trânsito de atores e práticas deliberativas que podem ter impacto na maneira como são capazes de colocar em ação as diferentes generalidades sociais pensadas por Rosanvallon. Parkinson (2003) se situa nessa linha de raciocínio ao buscar uma explicação para a legitimidade dos atores no processo deliberativo, frente à ausência de autorização de todos. Para ele, a legitimidade das deliberaçōes emerge na interseção entre a esfera pública e o Estado e não no interior de diferentes fóruns deliberativos (Parkinson, 2003, p. 186). É preciso avaliar o papel de cada um desses atores nos diferentes estágios do processo de tomada de decisōes, por exemplo, ponderando argumentos, sugerindo soluções e avaliando a implementação de políticas (Mendonça, 2010). Eles precisam ser pensados em suas conexōes com outros fóruns e instituiçōes, sendo dependentes da comunicação que ocorre na conversa cotidiana, do ativismo e dos diferentes fóruns representativos de tomada de decisão. Ou seja, a atividade representativa está diretamente conectada com práticas de participação e deliberação.

Isso implica conceber a representação democrática como uma interação contínua entre processo decisório no Estado e várias formas de discurso público, incluindo tanto a deliberação informal quanto as formas mais estruturadas de deliberação que ocorrem na sociedade civil (Brown, 2006, p. 206). No caso de instituições híbridas em que o processo decisório é partilhado entre Estado e sociedade, essa dicotomia precisa ser superada e as fronteiras flexibilizadas (Keck, 2003). Assim, em vez de focar na dualidade entre Estado que representa e sociedade que é representada, pode ser frutífero analisar a porosidade dessas esferas aos diferentes atores e discursos, bem como que tipo de legitimidade são capazes de evocar, lembrando sempre da relação contingente entre representação e legitimidade democrática.

\section{Consideraçôes finais}

O objetivo geral do artigo foi apresentar uma redefinição do conceito de representação política e seus critérios de legitimidade, tendo em vista a necessidade de se desvendar as dinâmicas de representação geradas pelas diversas formas de manifestação e expressão da sociedade civil. Com esses desafios à frente, o trabalho propôs avaliar a representação na contemporaneidade a partir de três questôes: quem, o que e como se representa. Esse movimento exigiu a atenção às diferentes formas de inclusão dos representantes, ao conteúdo a ser representado e à possibilidade de controle e responsividade. Foram elencados os principais elementos apontados pela literatura, que visavam lidar com o problema da representatividade. Desse modo, a resposta à questão "quem representa" pode direcionar para representantes escolhidos pelas características descritivas, autoautorizados perante a identificação com um conjunto de temas e discursos públicos e/ou indicados/eleitos pela afinidade e experiência com determinada política pública ou tema. Esses são elementos que podem ajudar a desvendar o mecanismo que ativa a representação, mas não dizem tudo sobre o processo de construção de demandas que sejam representativas. Mesmo nos espaços híbridos, em que é importante olhar para os processos de seleção, uma vez que esse é um mecanismo que não está "aberto" a todos os indivíduos, a simples presença de eleição ou métodos plurais de sele- 
ção não é garantia de democratização na definição de políticas públicas.

Em relação à redefinição "do que se representa”, mostrou-se que a pluralização de atores e espaços com função representativa oferece uma alternativa à expressão de interesses ou preferências agregadas territorialmente no momento eleitoral. A fim de fugir da legitimidade como ato de "contar cabeças", a literatura vem destacando a importância de mudar a percepção do que deve ser representado, incluindo as noções de perspectivas sociais, opiniōes e discursos ao lado da representação de interesses. $\mathrm{O}$ trabalho também alertou para as especificidades dos atores e espaços de representação, a fim de avaliar o que está sendo representado. Isso implica adicionar a questão "onde se representa" que, embora não tenha recebido a atenção teórica dedicada às três questôes, perpassa todo o trabalho. Enquanto na representação eleitoral o que se representa são pessoas a partir de sua autorização individual, entre os atores da sociedade civil há uma diferenciação entre aqueles que falam pelas pessoas e apresentam temas ou discursos perante o poder político e a sociedade e aqueles que representam o poder no sentido de tomar decisões em nome das pessoas, baseados na autorização dos atores sociais e estatais.

É importante lembrar que, nos diferentes casos, a representação envolve uma dimensão dinâmica e construtiva, que não exclui a importância do controle democrático. Em outras palavras, o representante apresenta reivindicaçōes representativas que não são, a priori, boas ou más, mas precisam estar abertas à interpretação e compreensão dos representados ou pessoas afetadas. Para isso, o processo político de apresentação de demandas precisa estar aberto e/ou atento ao público ao qual se destina atrair e convencer. O que implica repensar como se representa, não só como movimento de prestação de contas a um público específico, mas também de justificação pública de seus atos e propostas. Tal justificação não é dependente apenas de uma definição clara de quem são os constituintes ou de mecanismos institucionalizados. Isso não quer dizer que não existem formas institucionalizadas de controle dos representantes da sociedade civil. Em alguns espaços híbridos de interação entre Estado e sociedade, ou em organizaçôes civis e movimentos sociais, que possuem um público delimitado sobre o qual reivindicam representar, é possível visualizar formas de controle mais direto, seja por parte das entidades, seja do público ao qual representam. A literatura aponta ainda para o controle mútuo exercido entre organizaçōes civis, redes de políticas e mídia. Por fim, deve-se lembrar que as organizações da sociedade civil e seus atores também podem estar sujeitos ao próprio controle do Estado e das instituiçôes tradicionais de supervisão, tais como os tribunais.

A atenção a essas três questóes implícitas na atividade representativa implicou numa releitura mais geral do conceito de representação política. A partir do contraste entre Urbinati e Rosanvallon é possível defender que a representação não opera a cisão entre Estado e sociedade. Da maneira concebida pela autora, a produção da cisão parece confinar a representação à esfera estatal. Propõe-se avaliar a representação política como atividade que permite o social se tornar político ou que conecta o mundo do político à política. Essa conexão é operada por atores estatais e sociais, sem, é claro, romper com a diferença no exercício da autoridade e da representação entre esses atores.

A legitimidade democrática não está dada, mas é contingencialmente buscada na qualidade do processo representativo. Nessa direção, associações ou grupos podem adquirir ou perder legitimidade como representantes (Mendonça, 2008). A legitimidade nunca está, pois, adquirida (Rosanvallon, 2009, p. 29); ela é sempre precária, permanentemente questionada, dependente da percepção social da ação e do comportamento das instituiçõoes. Conforme destaca Parkinson (2003, p. 184), a legitimidade é um ideal regulatório, não um ponto fixo em uma escala: o que é legítimo em um contexto poderá ser ilegítimo em outro.

A redefinição de quem, o que e como se representa sugere que a legitimidade democrática precisa ser avaliada a cada caso, no processo de inclusão dos atores, na maneira em que os fóruns ou esferas deliberativas apresentam a pluralidade de demandas e no controle exercido interna e externamente ao fórum, na sua abertura e interação com outros atores, espaços e esfera pública. Outra constatação importante é que as três questóes, quem, o que e como se represen- 
ta, parecem formuladas na teoria liberal de maneira integrada, uma determinando a outra. Ou seja, a autorização de todos tem o papel tanto na definição do representante quanto do conteúdo a ser representado - pessoas e interesses agregados - e no relacionamento representativo - o controle exercido no momento eleitoral. $\mathrm{O}$ que a experiência da representação eleitoral mostra e a representação da sociedade civil confirma é que essas dimensões precisam ser vistas de forma desagregada, apesar de mutuamente relacionadas. Isto é, a legitimidade da autorização recebida pelo representante e a consideração matematicamente igual do indivíduo não garantiu, ao longo dos séculos, a igualdade de condiçốes de governar e de consideração das demandas representativas. Da mesma forma, a capacidade da sociedade civil alterar a definição de quem representa, introduzindo novos temas e discursos, pode ou não vir acompanhada de uma transformação no processo representativo, no que se refere ao conteúdo da representação e à prestação de contas e responsividade.

\section{Notas}

1 Santos (1981, p. 163) adverte que a noção de plenitude está implícita no conceito de soberania, uma vez que só assim ela seria suficientemente forte para ser exercida na forma de lei que obriga a todos.

2 Além da desconfiança dos liberais quanto ao processo eleitoral, a proposta de Edmund Burke defendia a representação virtual, baseado na ideia de que a representação deveria garantir a presença de grupos com divergências substantivas no Parlamento, não necessariamente a manifestação de todos no voto. $\mathrm{O}$ melhor interesse da nação surgiria da deliberação e consequente identificação de interesses objetivos da nação e não da expressão dos interesses de todos os indivíduos nas eleições.

3 Brown (2006, p. 209) argumenta que a seleção randômica oferece uma maneira impessoal, mecânica e quase-científica de selecionar representantes. $\mathrm{Na}$ medida em que a autoridade científica é vista universalmente como válida e, portanto, um tipo público de autoridade, a seleção por sorteio oferece uma forma simbólica de autorização pública.

4 Fraser (2007, p. 313), recentemente, passou a incluir na sua teoria da justiça a representação como sua ter- ceira dimensão política, em conjunto com as dimensões de reconhecimento (cultural) e de redistribuição (econômica). Para a autora, a representação é responsável por nos dizer quem é incluído ou excluído do círculo daqueles que têm o direito da justa distribuição e do reconhecimento recíproco.

5 Esses grupos podem ser formados tanto por apenas pessoas experts na área ou que têm alguma identificação com a causa, como também inserir pessoas que compartilham tais atributos.

6 Agradeço os comentários de Adrian Lavalle e Paulo D'Avila no $35^{\circ}$ Encontro da Anpocs, que destacaram a importância de se analisar os autores a partir desta distinção. Enquanto Nadia Urbinati trabalha com o registro da teoria política, buscando um modelo normativo para pensar o governo representativo, Rosanvallon se aproxima da teoria social, na medida em que a representação só faz sentido se pensada ao longo do tempo e a partir de sua constante reconfiguração.

7 O apelo à imparcialidade está presente nas agências reguladoras, conselhos técnicos e comissões por serem considerados mais objetivos e aptos à busca da unanimidade alcançada de modo imparcial. Já o principal exemplo da reflexividade são as Cortes Constitucionais, que têm o papel de multiplicar os enfoques parciais e plurais do bem comum. Destacam o papel reflexivo da democracia, contrário ao distanciamento presente no ideal de imparcialidade.

8 De acordo com Hendriks (2006), cada uma dessas esferas é responsável por integrar atores variados e são distintas em termos da sua maior ou menor porosidade a interesses alternativos ou marginalizados. A esfera micro representa as arenas do Estado; a macro, o espaço informal da sociedade e seus atores; e a mista, os espaços deliberativos de interação entre distintos atores (ver figura 2, Hendriks, 2006, p. 500).

\section{BIBLIOGRAFIA}

ABERS, Rebecca \& KECK, Margaret E. (2008), "Representando a diversidade: Estado, sociedade e 'relaçōes fecundas' nos conselhos gestores". Caderno CRH, 21 (52): 99-112.

ALMEIDA, Debora Rezende. (2010), "Metamorfose da representação política: lições práticas dos conselhos de saúde no Brasil", in L. Avritzer (org.), A dinâmica da participação local no Brasil, São Paulo, Cortez: 129-174. 
(2011), Repensando representação política e legitimidade democrática: entre a unidade e a pluralidade. Tese de doutorado. Belo Horizonte, UFMG.

ALVAREZ, Sonia; DAGNINO, Evelina \& ESCOBAR, Arturo (orgs.). (2000), Cultura e politica nos movimentos sociais latino-americanos: novas leituras. Belo Horizonte, Editora UFMG.

ARAUJO, Cicero. (2009), "Representação, soberania e a questão democrática". Revista Brasileira de Ciência Politica, (1): 47-61.

AVRITZER, Leonardo. (2007), "Sociedade civil, instituições participativas e representação: da autorização à legitimidade da ação". Dados, 50 (3): 443-464.

BROWN, Mark B. (2006), "Survey article: citizen panels and the concept of representation". The Journal of Political Philosophy, 14 (2): 203-225.

CASTIGLIONE, Dario \& WARREN, Mark E. (2006), "Rethinking democratic representation: eight theoretical issues". Annals of Rethinking Democratic Representation Workshop, University of British Columbia Press: 1-21.

DRYZEK, John S. (2001), "Legitimacy and economy in deliberative democracy". Political Theory, 29 (5): 651-669.

DRYZEK, John \& NIEMEYER, Simon. (2008), "Discursive representation". American Political Science Review, 102 (4): 481-493.

FISHKIN, James. (2009), When the people speak: deliberative democracy and public consultation. Oxford, Oxford University Press.

FRASER, Nancy. (2007), "Identity, exclusion, and critique: a response to four critics". European Journal of Political Theory, 6 (3): 305-338.

GAVENTA, John. (2004), "Representation, community leadership and participation: citizen involvement in neighbourhood renewal and local governance". Institute of Development Studies. Disponível em <www.dfid.gov.uk/ r4d/PDF/Outputs/CentreOnCitizenship/JGNRU.pdf>. Acesso em 18 jun. 2010.

GUTMANN, Amy; THOMPSON, Dennis. (2000), Democracy and disagreement. Cambridge, Harvard University Press.

HABERMAS, Jürgen. (2003), Direito e democracia: entre facticidade e validade. Tradução de Flávio
Beno Siebeneichler. 2 ed. Rio de Janeiro, Tempo Brasileiro, 2 vol.

HENDRIKS, Carolyn. (2006), "Integrated deliberation: reconciling civil society's dual role in deliberative democracy". Political Studies, 54 (3): 486-508.

HOBBES, Thomas. (1997), Leviatã, ou, Matéria, forma e poder de um Estado eclesiástico e civil. São Paulo, Nova Cultural (col. Os Pensadores).

KECK, Margaret E. (2003), "Governance regimes and the politics of discursive representation", in N. Piper \& A. Uhlin (eds.), Transnational activism in Asia: problems of power and democracy, Londres, Routledge, pp. 43-60.

KNIGHTS, Mark. (2009), "Participation and representation before democracy: petitions and addresses in premodern Britain”, in I. Shapiro et al. (eds.), Political representation, Cambridge, Cambridge University Press, pp. 35-57.

LAVALLE, Adrian Gurza; HOUTZAGER, Peter \& CASTELLO, Graziela. (2006), "Democracia, pluralização da representação e sociedade civil”. Lua Nova, (67): 49-103. Disponível em <http://www.scielo.br/pdf/ln/n67/a04n67.pdf >. Acesso em 15 mar. 2008.

LAVALLE, Adrian Gurza \& ARAUJO, Cicero. (2008), "O debate sobre a representação política no Brasil: nota introdutória”. Caderno $C R H$, 21 (52): 9-12.

LAVALLE, Adrian Gurza \& CASTELLO, Graziela. (2008), "Sociedade civil, representação e a dupla face da accountability: cidade do México e São Paulo". Caderno CRH, 21 (52): 67-86.

LOUREIRO, Maria Rita. (2009), "Interpretações contemporâneas da representação". Revista Brasileira de Ciência Política, (1): 63-93.

LÜCHMANN, Lígia. (2008), "Participação e representação nos conselhos gestores e no orçamento participativo". Caderno CRH, 21 (52): 87-97.

MAIA, Rousiley. (2012), "Representação política de atores cívicos: entre a imediaticidade da experiência e discursos de justificação". Revista Brasileira de Ciências Sociais, 27 (78): 97-112.

MANIN, Bernard. (1997), The principles of representative government. Cambridge, Cambridge University Press.

MANSBRIDGE, Jane. (2003), "Rethinking repre- 
sentation". American Political Science Review, 97 (4): 515-527.

MENDONÇA, Ricardo Fabrino. (2008), "Representation and deliberation in civil society". Brazilian Political Science Review, 2 (2): 117-137. (2010), "Democracia discursiva: contribuições e dilemas de uma abordagem deliberativa”. Anais do $7^{\circ}$ encontro da Associação Brasileira de Ciência Politica, Associação Brasileira de Ciência Política:1-25.

MIGUEL, Luis Felipe. (2003), "Representação política em 3-D: elementos para uma teoria ampliada da representação política”. Revista Brasileira de Ciências Sociais, 18 (51): 123-140. (2011), "Representação democrática: autonomia e interesse ou identidade e advocacy”. Lua Nova, 84: 353-364.

MILL, John Stuart. (1981), Considerações sobre o governo representativo. Brasília, Editora da UnB.

MOUFFE, Chantal. (2005), "Por um modelo agonístico de democracia". Revista de Sociologia e Política, Curitiba, (25):11-23.

PARKINSON, John. (2003), "Legitimacy proble$\mathrm{ms}$ in deliberative democracy". Political Studies, 51 (1): 180-196.

PATEMAN, Carole. (1992), Participação e teoria democrática. Rio de Janeiro, Paz e Terra.

PHILLIPS, Anne. (1995), The politics of presence. Oxford, Oxford University Press.

(2009), "Da desigualdade à diferença: um caso grave de deslocamento?". Revista Brasileira de Ciência Politica, (2): 223-240.

PITKIN, Hanna F. (1967), The concept of representation. Berkeley, University of California Press.

PLOTKE, David. (1997), "Representation is democracy”. Constellations, 4 (1): 19-34.

POLLAK, Johannes. (2007), "Contested meanings of representation". Comparative European Politics, 5 (1): 87-103.

ROSANVALLON, Pierre. (2006), Democracy past and future. Nova York, Columbia University Press.

(2009), La legitimidad democrática: imparcialidad, reflexividad, proximidad. Buenos Aires, Manantial.

RUNCIMAN, David. (2009), "Hobbes's theory of representation: anti-democratic or proto-democratic?", in I. Shapiro et al. (eds.), Political representation, Cambridge, Cambridge University Press: 15-34.

SAMUELSON, Charles D. et al. (2005), "Citizen participation and representation in collaborative engagement processes", in C. Samuelson et al. (eds.), Swimming upstream: collaborative approaches to watershed management. Cambridge, MA, MIT Press, pp. 137-169.

SANTOS, Wanderley Guilherme. (1981), "Reflexões sobre a questão do liberalismo: um argumento provisório", in B. Lamounier, F. Weffort e M. V. Benevides (orgs.), Direito, cidadania e participação, São Paulo, T. A. Queiroz, pp. 155-188.

SAWARD, Michael. (2005), "Governance and the transformation of political representation", in J. Newman (ed.), Remaking governance: people, politics and the public sphere, Bristol, RU, Policy Press, pp. 179-196.

(2006), "The representative claim". Contemporary Political Theory, (5): 297-318.

SCHMITTER, Philippe. (1992), "The consolidation of democracy and representation of social groups". American Behavioral Scientist, 35 (4/5): 422-449.

(2007), "The politics of organized interests". Conference Rethinking Representation: a north-south dialogue, Bellagio Study and Conference Center, pp. 1-22.

SCHUMPETER, Joseph. (1984), Capitalismo, socialismo e democracia. Tradução de Sérgio Góes de Paula. Rio de Janeiro, Zahar Editores.

SKINNER, Quentin. (2005), "Hobbes on representation". European Journal of Philosophy, 13 (2): 155-184.

SILVA, Ricardo. (2009), "Pierre Rosanvallon e as metamorfoses da legitimidade democrática". Anais do XVI Congresso Brasileiro de Sociologia, SBS.

TOCQUEVILLE, Alexis. (2000), A democracia na América: sentimentos e opiniōes. Tradução de Eduardo Brandão. São Paulo, Martins Fontes, vol. 2.

(2005), A democracia na América: leis e costumes. Tradução de Eduardo Brandão. São Paulo, Martins Fontes, vol. 1.

URBINATI, Nadia. (2006), Representative demo- 
cracy: principles and genealogy. Chicago, University of Chicago Press.

URBINATI, Nadia \& WARREN, Mark E. (2008), "The concept of representation in contemporary democratic theory". Annual Review of Political Science, 11: 387-412.

VIEIRA, Mónica \& RUNCIMAN, David. (2008), Representation. Cambridge, RU, Polity Press.

YOUNG, Iris Marion. (2000), Inclusion and democracy. Oxford, Oxford University Press (Oxford Political Theory). (2006), "Representação política, identidades e minorias". Lua Nova, (67): 139-190. 


\section{A RELAÇÃO CONTINGENTE ENTRE REPRESENTAÇÃO E LEGITIMIDADE DEMOCRÁTICA SOB A PERSPECTIVA DA SOCIEDADE CIVIL}

\section{Débora Rezende de Almeida}

Palavras-chave: Representação; Legitimidade; Democracia; Pluralização; Sociedade civil.

O objetivo deste artigo é apresentar uma revisão do conceito de representação política e seus critérios de legitimidade sob a perspectiva da sociedade civil. O estudo é motivado pelas transformações nas relações entre Estado e sociedade e pelo surgimento de atores representativos fora da dinâmica eleitoral. Propomos uma avaliação da representação na contemporaneidade a partir da redefinição de três questóes: quem, o que e como se representa. Esse movimento exige a atenção às formas de inclusão dos representantes, ao conteúdo a ser representado e à possibilidade de prestação de contas e responsividade. Por fim, defendemos que a construção de um conceito plural de representação deve superar a noção monista de legitimidade focada no Estado e no procedimento eleitoral. A relação entre representação e legitimidade democrática é contingente e construída durante o processo representativo.

\section{THE CONTINGENT RELATIONS BETWEEN REPRESENTATION AND DEMOCRATIC LEGITIMACY FROM THE PERSPECTIVE OF THE CIVIL SOCIETY}

\section{Débora Rezende de Almeida}

Keywords: Representation; Legitimacy; Democracy; Pluralization; Civil society.

The overall purpose of this paper is to present a review of the concept of political representation and its criteria of legitimacy from the perspective of civil society. The study is motivated by changes in the relations between State and society and the emergence of representative actors outside the electoral dynamics. It proposes to assess contemporary representation on the basis of a redefinition of three questions: who represents, what is represented and how representation occurs. This movement requires attention to the ways of inclusion of representatives, to the content to be represented, and to the possibility of accountability and responsiveness. Finally, the paper argues that the construction of a plural concept of representation must overcome the monistic concept of legitimacy focused on the sphere of the State and the electoral procedure. The relationship between representation and democratic legitimacy is contingent and constructed during the representative process.

\section{LE RAPPORT CONTINGENT ENTRE LA REPRÉSENTATION ET LA LÉGITIMITÉ DÉMOCRATIQUE DE LA PERSPECTIVE DE LA SOCIÉTÉ CIVILE}

\section{Débora Rezende de Almeida}

Mots-clés: Représentation; Légitimité; Démocratie ; Pluralisation; Société civile.

L'objectif de cet article est de présenter une révision du concept de représentation politique et de ses critères de légitimité à partir de la perspective de la société civile. L'étude est motivée par les transformations dans les relations entre l'État et la société et par l'intervention d'acteurs représentatifs en dehors de la dinamique électorale. Nous proposons une évaluation de la représentation dans la contemporanéité à partir de la redéfinition de trois questions: qui, quoi et comment se représente. Ce mouvement exige l'attention aux formes d'inclusion des représentants, au contenu à être représenté et à la possibilité de rendre des comptes et de sensibilité. En conclusion, nous défendons que la construction d'un concept pluriel de représentation doit surmonter la notion moniste de légitimité ciblée sur l'État et sur la procédure électorale. Le rapport entre la représentation et la légitimité démocratique est contingent et construit pendant tout au long du processus représentatif. 